\title{
CHROMATOGRAPHIC DETERMINATION OF SHIKIMATE FOR IDENTIFICATION OF CONVENTIONAL SOYBEAN AND GLYPHOSATE RESISTANT SOYBEAN
}

\author{
DETERMINAÇÃO CROMATOGRÁFICA DE CHIQUIMATO PARA IDENTIFICAÇÃO \\ DE SOJA CONVENCIOLNAL E RESISTENTE AO GLIFOSATO
}

\author{
Edicléia Aparecida BONINI'; Rogério MARCHIOSI²; Patrícia da Costa ZONETTI ${ }^{3}$; \\ Luiz Henrique Saes ZOBIOLE ${ }^{4}$; Osvaldo FERRARESE-FILHO ${ }^{2}$ \\ 1. Universidade Tecnológica Federal do Paraná, PR, Brasil, edicleiaa@ utfpr.edu.br; 2. Professor, Doutor, Universidade Estadual de \\ Maringá, PR, Brasil; 3. Professora, Doutora, Universidade Federal do Paraná, PR, Brasil; 4. Pesquisador, Crop Protection R\&D, PR, \\ Brasil.
}

\begin{abstract}
A sensitive and reliable process was established using high-performance liquid chromatography (HPLC) to distinguish conventional varieties of glyphosate-resistant genetically modified crops via shikimate detection in soybean (Glycine max L. Merril) seeds. Glyphosate has a well-defined mechanism of action. It is the only herbicide that specifically inhibits 5-enolpiruvilshikimate-3-phosphate synthase (EPSPS E.C. 2.5.1.19), which catalyzes the condensation of shikimate with phosphoenolpyruvate. This study is based on the concept that shikimate significantly accumulates in soybean plant tissues after EPSPS inhibition by glyphosate. In plants not subjected to glyphosate, shikimate is not easily detected because it quickly metabolizes into shikimate 3-phosphate and subsequently into 5-enolpiruvilshikimate 3-phosphate through the action of EPSPS. Conversely, in non-genetically modified plants subjected to glyphosate, shikimate metabolism is impaired, resulting in its accumulation. This metabolite can be detected in extremely low quantities (in the microgram range), through HPLC. In this study, six different contrasts were analyzed, each being formed by a transgenic cultivation and its parental strain, subject or not subject to the treatment of soaking with a $0.6 \%$ glyphosate solution. Chromatographic analyses indicated shikimate accumulation only in conventional cultivars with seeds previously soaked in a $0.6 \%$ glyphosate solution. Thus, this shikimate detection method can be used as a rapid and accurate means to distinguish soybeans with glyphosate-resistant qualities.
\end{abstract}

KEYWORDS: Glycine $\max$ L. Merril. Transgenesis. RR soybean. HPLC.

\section{INTRODUCTION}

Herbicide tolerance is one of the first transgenic characteristics to be successfully incorporated into commercial crops. This was accomplished through the development of Roundup Ready (RR) crops, which are tolerant to the herbicide glyphosate. This technology has provided noteworthy benefits for farmers because it implies crop tolerance towards a broad spectrum of glyphosate-containing herbicides (VELINI et al., 2008). Glyphosate is an active ingredient of herbicides that inhibits the enzyme EPSPS, present in the shikimate pathway. This pathway is one of the major biosynthetic pathways in higher plants responsible for linking carbohydrate metabolism to the production of the aromatic amino acids (AAAs), L-phenylalanine (Phe), L-tyrosine (Tyr), and Ltryptophan (Trp). All three AAAs are derived from intermediates of the same series of reactions in the shikimic acid pathway (TOHGE et al., 2013). Glyphosate inhibition of the pathway prevents the plant from synthesizing essential amino acids required for protein synthesis as well as some secondary metabolites (KRUSE et al., 2000). In plants, the onset of macroscopic symptoms of glyphosate phytotoxicity is slow. The death of a non-transgenic plant occurs several days after glyphosate application. However, some biochemical aspects can be checked within a few hours of its application (KREMER et al., 2005, DUKE; POWLES, 2008).

The function of EPSPS is to catalyze the transfer of the enolpyruvyl moiety of phosphoenolpyruvate (PEP) to the 5-hydroxyl of shikimate-3-phosphate (S3P). As glyphosate and PEP share the same binding site in the enzyme, the presence of this herbicide inhibits enzyme action in the plant. RR cultivars overcome this inhibition by the presence of CP4 EPSPS, characterized by their reduced affinity to glyphosate (FUNKE et al. 2006). Shikimate accumulation is known to be a direct result of enzymatic inhibition by glyphosate; therefore, its quantification can be correlated with 
Chromatographic...

the insertion of the herbicide-resistance gene, as in the case of RR soybeans.

Global production of genetically modified (GM) seeds has reached significant proportions. In Brazil, the use of transgenic cultivars reached $95 \%$ in the 2018 crop (CONTINI et al 2018). However, as there are niche markets that do not accept genetically modified products, strategies and methods for detecting GM varieties are relevant and require regulation in the certification process, especially in the seed market. These regulations demand reliable methods for detecting small differences between conventional and genetically modified plant species. In general, such methods include nucleic acid amplification methods, proteinbased methods, and detection of enzymatic activity, among others (QUERCI et al. 2010). Such methodology is in demand, especially rapid methods with lowcost that can certify the genetic purity of crops at different times, such as during the crop cycle or through the analysis of stored seeds.

A generally accepted approach to generate data for the detection of GM varieties is based on a comparative assessment of characteristics (phenotypic, agronomic, ecological, and physiological) between GM plants and conventional non-GM varieties. In this context, in the present
BONINI, E. A. et al.

study, the technique developed by Bonini et al. (2009) was applied with some modifications to assure a rapid, sensitive, and safe alternative to differentiate glyphosate-resistant soy from conventional soy. In the future, such a technique could be utilized by interested agencies, especially companies, to develop control strategies linked to the production of seeds. In this study, a chromatographic technique was used for the quantification of shikimate in the rootlets of different transgenic and conventional soybean varieties, which were subjected to treatment with a commercially used glyphosate herbicide.

\section{MATERIAL AND METHODS}

Twelve cultivars comprising six conventional cultivars and their transgenic RR variants (Table 1) were analyzed in this study and were provided by Embrapa Soybean (Londrina-PR) and CTPA - Technological Centre for Agricultural Research (GO). The commercial-grade glyphosate used in this study contained $360 \mathrm{~g} \mathrm{~L}^{-1}$ of equivalent acid (e.a.), $480 \mathrm{~g} \mathrm{~L}^{-1}$ of isopropylamine salt of $N$ (phosphonomethyl) glycine $\left(\mathrm{C}_{3} \mathrm{H}_{8} \mathrm{NO}_{5} \mathrm{P}\right)$, and $684 \mathrm{~g}$ $\mathrm{L}^{-1}$ of inert ingredients.

Table 1. Evaluated soybean cultivars.

Conventional cultivars

Transgenic cultivars

$\begin{array}{cc}\text { BRS 133 } & \text { BRS 245 RR } \\ \text { BRS 137 } & \text { BRS 255 RR } \\ \text { Embrapa } 48 & \text { BRS 242 RR } \\ \text { Emgopa 313 } & \text { Emgopa 313 RR } \\ \text { Emgopa 315 } & \text { Emgopa 315 RR } \\ \text { Emgopa 316 } & \text { Emgopa 316 RR }\end{array}$

The seeds were immersed in $300 \mathrm{~mL}$ of a commercial herbicide (Roundup Ready ${ }^{\circledR} 0.6 \%$ isopropylamine salt of $N$-(phosphonomethyl) glycine $480 \mathrm{~g} \mathrm{~L}^{-1}$, glyphosate acid equivalents $360 \mathrm{~g}$ $\mathrm{L}^{-1}$, inert ingredients $692 \mathrm{~g} \mathrm{~L}^{-1}$ ) for $4 \mathrm{~h}$. The time and concentration variables were determined through a soaking curve determined via prior experiments performed in Plant Biochemistry laboratory at the State University of Maringá. Control samples were subjected to similar conditions, but the seeds were soaked in water.

After $4 \mathrm{~h}$ of water immersion, the seeds were placed between two sheets of Germitest ${ }^{\circledR}$ paper moistened with water and rolled up and allowed to germinate in a darkroom at $25^{\circ} \mathrm{C}$ and $80 \%$ relative humidity for $24 \mathrm{~h}$. On average, four Germitest ${ }^{\circledR}$ rolls containing 25 seeds each were prepared from each cultivar. After the germination period, shikimate was extracted from the rootlets of the seedlings.

For the extraction of shikimate, the vegetable tissue was macerated using a mortar and pestle with $0.25 \mathrm{~N} \mathrm{HCl}$ (1:3 weight/volume). This was followed by centrifugation at $1200 \times g$ for 10 
min, after which the supernatant was separated for further analysis (MARCHIOSI et al. 2009).

The samples obtained were previously diluted (50-100 times) in the mobile phase (aqueous solution of $\mathrm{H}_{3} \mathrm{PO}_{4} 3.5 \mathrm{mM}$ ) and then filtered through a syringe adapted to a filter with a polyvinylidene difluoride membrane with a porosity of $0.45 \mu \mathrm{m}$. Subsequently, the sample was injected into a Shimadzu $^{\circledR}$ Liquid Chromatograph (Tokyo, Japan) equipped with a LC-10AD pump, a Rheodyne ${ }^{\circledR}$ injector, a SPD-10A UV detector, a CBM-101 Communications Bus Module, and a Class-CR10 workstation system. A reversed-phase Shimpack ${ }^{\circledR}$ CLC-ODS (M) column $(150 \times 4.6 \mathrm{~mm}, 5 \mathrm{~m})$ was used at room temperature, together with the same type of pre-column $(10 \times 4.6 \mathrm{~mm})$. Elution was performed in isocratic conditions over the course of $10 \mathrm{~min}$, and the shikimate was identified at $220 \mathrm{~nm}$. Shikimate was identified by comparison of its retention time with that of a standard, at $3.5 \mu \mathrm{g} \mathrm{mL}$ ${ }^{1}$, which was prepared and injected under the same conditions described for the samples.

The amount of shikimate in the samples was determined according to the formula: shikimate $(\mu \mathrm{g}$ $\left.\mathrm{g}^{-1}\right)=\mathrm{F} \times($ sample area / standard area $) \times$ dilution, where: sample area and standard area are the areas calculated, provided by the HPLC, and refer to the sample and the standard as eluted by the mobile phase. Dilution represents the number of times that a sample was diluted (50-100 times) in the mobile phase, while $\mathrm{F}\left(=10.5 \mu \mathrm{g} \mathrm{g}^{-1}\right)$ is the calculation factor obtained by the relationship between the concentration of the standard $\left(3.5 \mu \mathrm{g} \mathrm{mL}^{-1}\right)$ and the vegetable tissue extract $(0.5 \mathrm{~g}$ of fresh matter extracted in $1.5 \mathrm{~mL}$ of $\mathrm{HCl} 0.25 \mathrm{~N}$ ), according to the formula: $\mathrm{F}=3.5 \mu \mathrm{g} \mathrm{mL}^{-1} \times 1.5 \mathrm{~mL} \div 0.5 \mathrm{~g}$. All results are expressed in $\mu \mathrm{g}$ shikimate $\mathrm{g}^{-1}$ fresh vegetable tissue. A set quantity of $20 \mu \mathrm{m}$ of shikimate was injected into the vegetable tissue every day before the start of the HPLC analysis, and the retention time of the standard chromatogram was used to identify shikimate in the samples being analyzed. The experimental design used was completely randomized and performed in quadruplicate. Due to the qualitative methodology used in this study, the results were expressed as mean and standard deviation.

\section{RESULTS AND DISCUSSION}

Figure 1 represents the chromatographic profiles obtained from standard shikimate and the samples of shikimate extracted from conventional soybean rootlets (BRS 133) and transgenic samples (BRS 245RR). The conventional soybeans treated with $0.6 \%$ e.a. of commercial herbicide accumulated shikimate, which did not occur in the transgenic cultivar.

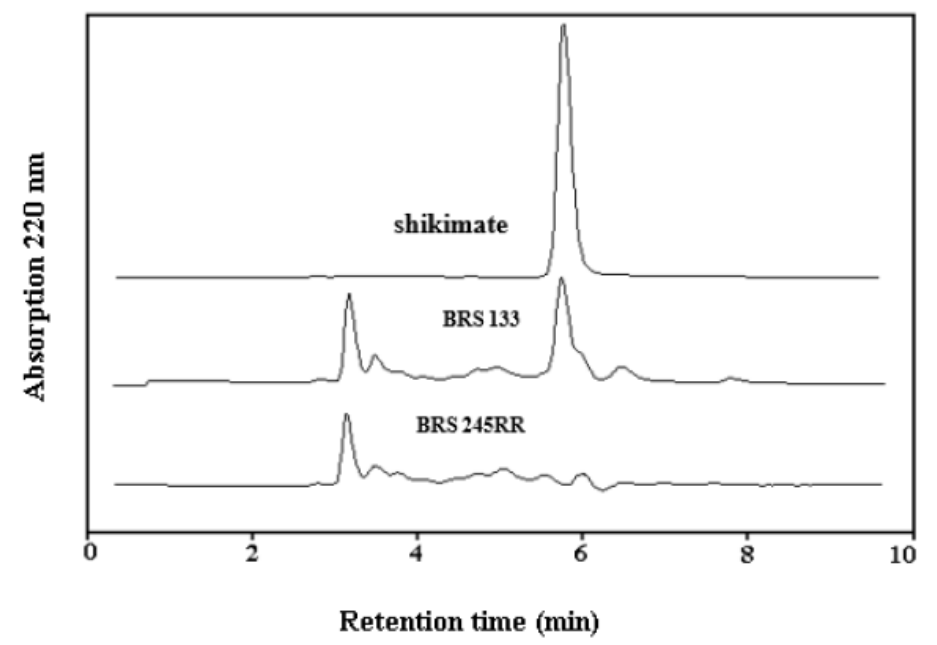

Figure 1. Representative chromatograms showing the pattern of shikimate $20 \mu \mathrm{M}$ (retention time Rt $=5.68$ min); shikimate $(\mathrm{Rt}=5.70 \mathrm{~min})$ accumulated in conventional soybean sprouts (BRS -133) treated with the commercial herbicide, and the absence of shikimate in soy sprouts resistant to glyphosate (BRS 245RR), treated with $0.6 \%$ of acid equivalent and the glyphosate herbicide.

Pline et al. (2002) evaluated the efficiency of chromatographic techniques compared to spectrophotometric techniques on their study on Gossypium hirsutum L., which was resistant or susceptible to glyphosate. Both spectrophotometry and HPLC demonstrated the accumulation of shikimate in conventional plants treated with glyphosate. However, after herbicidal application, the spectrophotometric technique detected $73 \%$ of shikimate, while $100 \%$ of shikimate was detected 
through HPLC. The effectiveness of these methods was also demonstrated by Bonini et al. (2009) and Marchiosi et al. (2009), who demonstrated shikimate accumulation in different tissues of soybean plants treated with glyphosate. However, in all the above studies, the results clearly indicate that chromatographic techniques effectively quantify the shikimate present in the samples without the interference normally found in spectrophotometric tests. These results demonstrate greater reliability for the methods employed in this work.

Via inhibitiion of the EPSPS enzyme, glyphosate leads to the accumulation of shikimate, which has consequently been used as a biomarker for glyphosate exposure. Gomes et al. (2017) investigating shikimate concentrations in seed embryos exposed to herbicide and observed that only non-GR embryos exposed to glyphosate accumulated shikimate; this accumulation was not observed in the RR variety. Franco et al. (2012) related the use of glyphosate in RR soybeans to shikimate accumulation in the leaves. In their experiments, shikimate accumulation at low levels was observed between the third and seventh day in RR soybeans plants treated with specific herbicides. However, the authors did not contrast these observations with those in conventional cultivars to distinguish the effects of the herbicide on shikimate accumulation in RR soybean plants as against their respective conventional cultivars.

To establish a reliable protocol, in the present study, several comparisons were made between conventional and transgenic soy seeds, with the results presented in Table 2 . In this study, significant shikimate accumulation was noted in the rootlets of conventional cultivars (>952.4 $\mu \mathrm{g} \mathrm{g}^{-1}$ ) after treatment with glyphosate. However, a similar result was not observed with transgenic soybean tissues, in which shikimate was not detected. As is commonly known, insertion of the glyphosate tolerance gene into a plant precludes perturbation in the shikimate pathway in response to herbicidal presence. This occurs via the maintenance of high levels of EPSPS activity, because of its low affinity to herbicides, thereby ensuring rapid metabolism of shikimate (PADGETTE et al. 1995).

Table 2. Shikimate levels in the rootlets of conventional glyphosate-resistant soybeans and those treated with a commercial herbicide $(0.6 \%)$.

\begin{tabular}{lc}
\hline Cultivars & Skimate $\left(\mu \mathrm{g} \cdot \mathrm{g}^{-1}\right.$ fresh vegetable tissue $)$ \\
\hline BRS 137 & $1.238 .1 \pm 52.5$ \\
BRS 255RR & nd \\
BRS 133 & $1.197 .2 \pm 20.3$ \\
BRS 245RR & nd \\
EMGOPA 316 & $1.107 .6 \pm 19.4$ \\
EMGOPA 316RR & nd \\
EMGOPA 313 & $1.030 .8 \pm 24.3$ \\
EMGOPA 313RR & nd \\
EMGOPA 315 & $1.020 .5 \pm 72.7$ \\
EMGOPA 315RR & nd \\
EMBRAPA 58 & $952.4 \pm 32.5$ \\
BRS 242RR & nd \\
\hline
\end{tabular}

Averages $(\mathrm{N}=4 \pm$ mean standard error); nd $=$ not detected

Figure 2 shows the chromatogram obtained through the analyses of the rootlets from BRS 137 and BRS 255RR cultivars, which were soaked in a glyphosate solution, along with the pattern of $20 \mu \mathrm{m}$ shikimate. As shown in Figure 3, analyses of the seeds immersed only in water did not indicate shikimate accumulation in any of the cultivars.
These chromatographic profiles were observed in all the contrasts evaluated. High shikimate content was detected in cultivars that did not contain the glyphosate resistance gene but not in the RR cultivars, thus demonstrating a clear differentiation between conventional cultivars and transgenic cultivars. 


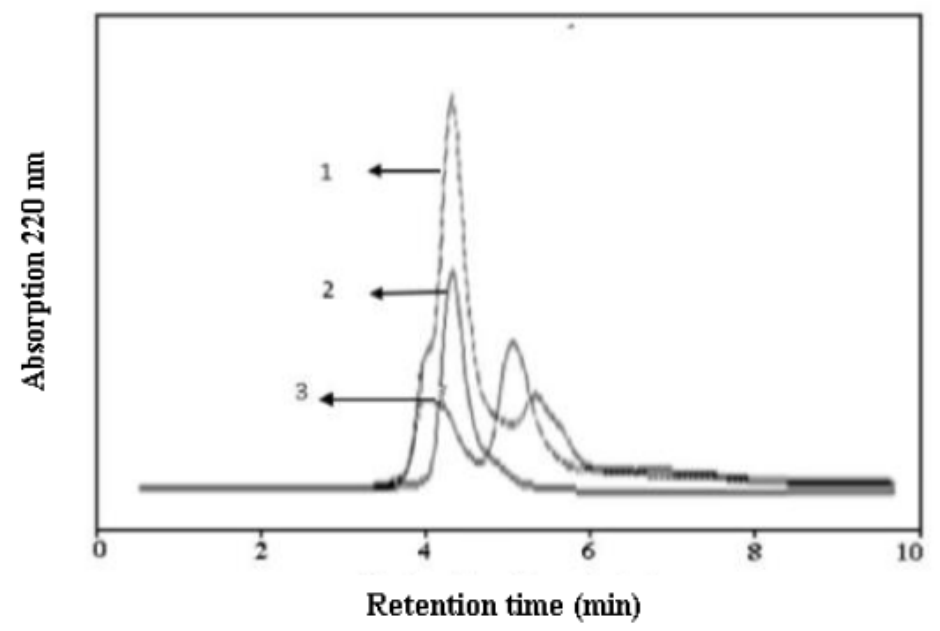

Figure 2. Chromatogram showing the pattern of shikimate $20 \mu \mathrm{M}$ (1). Chromatograms obtained through the analyses of the rootlets from BRS 137 (2) and BRS 255RR (3) cultivars, which were soaked in a glyphosate solution.

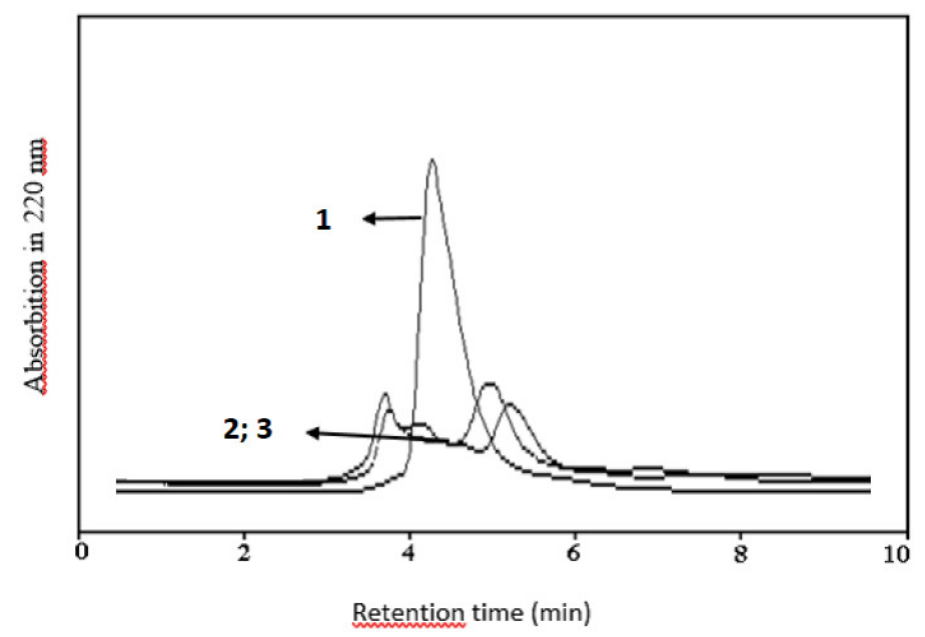

Figure 3. Chromatogram showing the pattern of shikimate $20 \mu \mathrm{M}$ (1). Chromatograms obtained through the analyses of the rootlets from BRS 137 (2) and BRS 255RR (3) cultivars, which were soaked in water.

Pereira et al. (2009) used the test with paper moistened with glyphosate solution as an initial screening of seeds to obtain samples for molecular confirmation by PCR. This method can significantly reduce the costs of certification for tolerance or sensitivity to herbicides in transgenic plants. The PCR analysis is a very sensitive and reliable technique, but, requires sophisticated equipment and expensive reagents. The pre-germination of seeds, with subsequent chromatographic analysis of shikimate content, represents an efficient method of comparing the cost benefit ratio of the examinationof soybean RR seeds.

\section{CONCLUSIONS}

The estimation of shikimate through a chromatographic technique is sufficient for distinguishing between conventional soybean plants and those resistant to glyphosate.

The reliability of the technique employed is reinforced by the results of comparisons between RR soybean varieties with their respective parental conventional cultivars.

The present technique facilitates qualitative analyses to determine the presence of RR soybeans and can be applied seed certification processes and the traceability of cultivars. 
RESUMO: Este estudo estabelece um processo, sensível e confiável, com aplicação de cromatografia líquida de alta eficiência (HPLC) para distinguir variedades de soja convencionais de geneticamente modificadas, resistentes ao glifosato, por detecção de chiquimato nas sementes. O mecanismo de ação do glifosato é bem definido. É o único herbicida que inibe especificamente a enzima 5-enolpiruvilchiquimato-3fosfato sintase (EPSPS, E.C. 2.5.1.19), que catalisa a condensação do chiquimato com fosfoenolpiruvato. $\mathrm{O}$ trabalho está baseado na concepção do chiquimato se acumular significativamente nos tecidos vegetais de soja convencional, após a inibição da EPSP sintase pelo glifosato. Em plantas não submetidas ao glifosato, o chiquimato não é facilmente detectado, pois rapidamente é metabolizado a chiquimato 3 -fosfato e, a seguir, em 5-enolpiruvilchiquimato 3-fosfato, pela ação da EPSPS. Por outro lado, em plantas não geneticamente modificadas submetidas ao glifosato, a metabolização do chiquimato é prejudicada, resultando em seu acúmulo. Este metabólito pode ser detectado em quantidades extremamente baixas (na faixa de $\mu \mathrm{g}$ ), por HPLC. Neste trabalho foram analisados seis contrastes diferentes, sendo cada contraste formado por uma cultivar transgênica e sua respectiva cultivar parental convencional, submetidas ou não a embebição com solução de glifosato $0,6 \%$. As análises cromatográficas indicaram o acúmulo de chiquimato apenas em cultivares convencionais, nas quais as sementes foram previamente embebidas em solução de glifosato $0,6 \%$. Os resultados demonstraram que a detecção de chiquimato pode ser utilizada como um método rápido e preciso na diferenciação de soja resistente ao glifosato de soja convencional.

PALAVRAS-CHAVE: Glycine max L. Merril. Transgenia. Soja RR. HPLC.

\section{REFERENCES}

BONINI, E.A.; FERRARESE, M.L.L.; MARCHIOSI, R.; ZONETTI, P.C.; FERRARESE, M.L.L.; MARCHIOSI, R.; ZONETTI, P.C.; FERRARESE-FILHO, O. A simple chromatographic assay to discriminate between glyphosate-resistant and susceptible soybean (Glycine max) cultivars. European Journal of Agronomy, v. 31, p. 173-176, 2009. https://doi.org/10.1016/j.eja.2009.03.006

CONTINI, E.; GAZZONI, D.; ARAGÃO, A.; MOTA, M.; MARRA, R. complexo soja - Caracterização e desafios tecnológicos. Brasília, DF, Embrapa, 2018. 35 p. Disponível em:

https://www.embrapa.br/documents/10180/0/COMPLEXO+SOJA++Caracteriza\%C3\%A7\%C3\%A3o+e+Desaf ios+Tecnol\%C3\%B3gicos/709e1453-e409-4ef7-374c-4743ab3bdcd6>. Acesso em: 17 de outubro de 2019.

DUKE, S.O.; POWLES, S.B. Glyphosate: a once-in-a-century herbicide. Pest Management Science, v. 64, p. 319-325, 2008. https://doi.org/10.1002/ps.1518

FRANCO, D.A.S.; ALMEIDA, S.D.B.; CERDEIRA, A.L.; DUKE, S.O.; MORAES, R.M.; LACERDA, A.L.S.; MATALLO, M.B. Evaluation of glyphosate application on transgenic soybean and its relationship with shikimic acid. Planta Daninha, v. 30, p. 659-666, 2012. https://doi.org/10.1590/S0100-83582012000300023

FUNKE, T.; HAN, H.; HEALY-FRIED, M.L.; FISCHER, M.; SCHÖNBRUNN, E. Molecular basis for the herbicide resistance of Roundup Ready crops. Proceedings of the National Academy of Sciences, v. 103, p. 13010-13015, 2006. https://doi.org/10.1073/pnas.0603638103

KREMER, R.J.; MEANS, N.E.; KIM, S. Glyphosate affects soybean root exudation and rhizosphere microorganisms. International Journal of Environmental Analytical Chemistry, v. 85, p. 1165-1174, 2005. https://doi.org/10.1080/03067310500273146

KRUSE, N.D.; TREZZI, M.M.; VIDAL, R.A. Herbicides EPSPS inhibitors: literature review. Revista Brasileira de Herbicidas, v. 1, p. 139-146, 2000. https://doi.org/10.7824/rbh.v1i2.328 
MARCHIOSI, R.; FERRARESE, M.L.L; BONINI, E. A.; FERNANDES, N. G.; FERRO, A. P.; FERRARESE-FILHO, O. Glyphosate-induced metabolic changes in susceptible and glyphosate-resistant soybean (Glycine max L.) roots. Pesticide Biochemistry and Physiology, v. 21, p. 155-164, 2009. https://doi.org/10.1016/j.pestbp.2008.09.003

PADGETTE, S.R.; KOLACZ , K.H.; DELANNAY, X.D.; LA VALLEE, B.J.; TINIUS, C.N.; RHODES, W.K.; OTERO, Y.I.; BARRY; G.F.; EICHHOLTAZ, D.A.; PESCHKE, W.M.; NIDA, D.L.; TAYLOR, N.B. Development, identification and characterization of a glyphosate tolerant soybean line. Crop Science, v. 35, p. 1451-1461, 1995. https://doi.org/10.2135/cropsci1995.0011183X003500050032x

PEREIRA, W.A.; LISBOA, S.P.; DIAS, D.C.F.S.; ALVARENGA, E.M.; BORÉM, A. Adjustment of methodologies for the identification of soybean cultivars for tolerance to glyphosate. Revista Brasileira de Sementes, v. 31, p. 133-144, 2009. https://doi.org/10.1590/S0101-31222009000400016

PLINE, W.A.; WILCUT, J.W.; DUKE, S.O.; KEITH, L.E.; WELLS, R. Tolerance and Accumulation of Shikimic Acid in Response to Glyphosate Applications in Glyphosate-Resistant and Nonglyphosate-Resistant Cotton (Gossypium hirsutum L.). Journal of Agricultural and Food Chemistry, v. 50, p. 506-512, 2002. https://pubs.acs.org/doi/10.1021/jf0110699

QUERCI, M., VAN DEN BULCKE, M., ŽEL, J., EEDE, G. V., BROLL, H. New approaches in GMO detection. Analytical and Bioanalytical Chemistry, v. 396, n. 6, p. 1991-2002, 2010. https://doi.org/10.1007/s00216-009-3237-3

TOHGE, T., WATANABE, M., HOEFGEN, R., FERNIE, A.R. Shikimate and phenylalanine biosynthesis in the green lineage. Frontiers in Plant Science, v. 4, p. 1-13, 2013. https://doi.org/10.3389/fpls.2013.00062

VELINI, E.D.; ALVES, E.; GODOY, M.C.; MESCHEDE, D.K.; SOUZA, R.T.; DUKE, S.O. Glyphosate applied at low doses can stimulate plant growth. Pest Management Science, v. 64, p. 489-496, 2008. https://doi.org/10.1002/ps.1562 